\title{
A Cross Sectional Study for Detection of Anti-HBs Antibody among Healthcare Workers
}

\author{
S. Ravikumar*, Radhika Katragadda and B. Abishek \\ Department of Microbiology, Govt. Medical College, Omandur Govt. Estate, \\ Chennai-600002, Tamil Nadu, India \\ *Corresponding author
}

\section{A B S T R A C T}

\begin{tabular}{|l|}
\hline K e y w o r d s \\
$\begin{array}{l}\text { Health Care Workers, } \\
\text { Anti-HBs Antibody, } \\
\text { Hepatitis B Vaccination, } \\
\text { ELISA }\end{array}$ \\
\hline Article Info \\
\hline $\begin{array}{l}\text { Accepted: } \\
\text { 18 May 2018 } \\
\text { Available Online: } \\
\text { 10 June } 2018\end{array}$ \\
\hline
\end{tabular}

\section{Introduction}

Hepatitis B infection is the tenth leading cause of death and it is one of the major global public health problems. Evidence shows that more than 2 billon of the population have past or recent $\mathrm{HBV}$ infection, and more than 350 million chronic carriers of this infection were found worldwide. (Previsani and Lavanchy, 2002) Among the general population in India, the prevalence of HBsAg ranges from 2 to 8 $\%$ and India is in the intermediate endemic zone for HBV (Previsani and Lavanchy, 2002; Gupta et al., 2008).

According to WHO, the proportion of healthcare workers in the general population varied

\begin{abstract}
Hepatitis B infection is the tenth leading cause of death and it is one of the major global public health problems with prevalence of $2 \%$ to $\%$ in India. Hepatitis B vaccination is required to protect Healthcare workers (HCW) from Hepatitis B infection. Very few data's are available from India on vaccination status of HCWs. This study is aimed to determine the Post vaccination status among Health Care workers in a tertiary care hospital. Blood samples were collected from $243 \mathrm{HCWs}$ and serum anti-HBs Ab levels were quantified by respond metho Among the HCW 96.05\% were responders and $4.95 \%$ were nonstudents. The percentage of non-responders can be brought down by checking the anti HBs level after completing the full course of vaccination and administrating the booster dose if the antibody level is found to be insufficient $(<10 \mathrm{mIU} / \mathrm{mL})$.
\end{abstract}

substantially by region $(0.2 \%-2.5 \%)$, as did the average number of injuries per health-care worker $(0.2 \%-4.7 \%$ sharps injuries per year). The annual proportion of health-care workers exposed to blood-borne pathogens was $5.9 \%$ for $\mathrm{HBV}$, corresponding to about $66,000 \mathrm{HBV}$ infections in health-care workers worldwide (Prüss-Üstün et al., 2005).

The fraction of HBV was less than $10 \%$, in developed regions, largely because of immunization and post-exposure prophylaxis (Prüss-Üstün et al., 2005). Although most of the HBV infections in healthcare workers are attributed to per-cutaneous exposure, in many studies, most infected HCWs could not recall any overt per-cutaneous injury (Garibaldi et 
al., 1973). Hepatitis B virus has been demonstrated to survive at room temperature in dried blood, on environmental surfaces, for atleast one week. Thus, HBV infections that occur in HCWs with no history of exposure might have resulted from direct or indirect blood or body fluid exposures, leading to inoculation of HBV into the mucosal surfaces or cutaneous scratches and other lesions (Lauer et al., 1979; US Public Health Service, 2001). The potential for HBV transmission through contact with environmental surfaces has been demonstrated in investigations of HBV outbreaks among patients and staff of hemodialysis units (Dienstag et al., 1984; Zajac et al., 1986).

HBV titre is highest in the blood when compared to the other body fluids and is the important vehicle of transmission in the healthcare settings. Hepatitis B vaccination is required to protect Healthcare workers from Hepatitis B infection. The 3-dose of vaccine series are administered intramuscularly at 0,1 , and 6 months interval induces a protective antibody response in approximately 30\%-$55 \%$ of healthy adults aged $\leq 40$ years after the first dose, $75 \%$ after the second dose, and $>90 \%$ after the third dose (Francis et al., 1982; Shaw et al., 1989)

Since 1992, the inclusion of hepatitis B vaccination has been recommended by the WHO in all immunization programs implemented by nations (http://www.cdc.gov/hepatitis/statistics/index. htm). In 1997, the CDC recommended that all healthcare workers should be vaccinated against Hepatitis B virus (ACIP and HICPAC, 1997). The International Standards define as protective antibody level (anti-HBs) higher than $10 \mathrm{IU} / \mathrm{L}$ after the primary vaccine series (CDC, 2012). Occupation Health and Safety Administration recommended Hepatitis B virus vaccination followed by confirmation of vaccine response in all Healthcare workers by initial Anti HBs assay within one to three months of primary immunization (McMahon et al., 2005).

Very few data's are available from India on vaccination status of HCWs. So it is important to know the awareness and attitude of HCWs regarding the Hepatitis B infection, vaccination and post-vaccination immune check-ups.

The study is aimed to check for the serological evidence of Hepatitis B immunity by detecting the Anti HBs titre levels in the Healthcare workers who had full course of Hepatitis B vaccination $(0,1,6$ month dose), by an anonymous cross sectional sero survey in a tertiary care hospital.

\section{Materials and Methods}

This is a cross-sectional serological study conducted at a Tertiary care Hospital, Chennai for a period of 6 months, after getting approval from Institutional Ethical

Committee.

Inclusion Criteria:

Healthcare workers $>18$ years.

Healthcare workers who have completed full course of Hepatitis B vaccination i.e, $0,1 \& 6$ doses.

\section{Exclusion Criteria:}

Healthcare workers not vaccinated or not completed the full course of Hepatitis B vaccine.

About 243 Health care workers, who fulfilled the inclusion criteria, were included in the study. Participant's details such as age, sex and the Vaccination history like: number of doses, date of vaccination, testing for post 
vaccination anti HBs titre and booster dose if any were documented.

After getting informed consent about $3 \mathrm{ml}$ of Venous Blood Sample was collected under strict aseptic precaution. Serum sample was separated and stored at $-20^{\circ} \mathrm{C}$, until tested.

After collecting all the samples the quantitative ELISA was performed using Dia. Pro HBsAb ELISA kit.

Quantitative analysis was done, by following manufacturer's instructions, as given in the kit manual.

A validation check was carried out with the OD value of the blanks, calibrators and the control sample to verify the performance of the assay.

The values obtained in our test matches the validation requirements. Calibration curve was made from the values obtained, then on the calibration curve the concentration of the anti $\mathrm{HBs} \mathrm{Ag}$ in the sample was calculated.

\section{Results and Discussion}

Among the study population, about 141 were males (58.03 \%) and 102 were females $(41.97 \%)$.

Among the study population $37.04 \%$ were doctors and Medical students respectively and Nurses were $25.92 \%$.

Among the 243 study population, 231 were responders $(95.06 \%)$ and 12 were non responders (4.94\%) (Chart: 1).Responders are those whose Anti-HBsAb body levels was $>10 \mathrm{mIU} / \mathrm{ml}$, following a full vaccination course. Non Responders are those whose Anti$\mathrm{HBs} \mathrm{Ab}$ body levels was $<10 \mathrm{mIU} / \mathrm{ml}$, following a full vaccination course.

Among the 231 Responders, 90 were doctors, 63 were nurses and 90 were Medical students. Among nurses $9.52 \%$ were non-responders when compared to doctors $(3.33 \%)$ and medical students $(3.33 \%)$ (Table: 2$)$

Table.1 Distribution of Study Population

\begin{tabular}{|l|l|l|}
\hline $\begin{array}{l}\text { STUDY } \\
\text { POPULATION(n=243) }\end{array}$ & NO. & PERCENTAGE \\
\hline Doctors & 90 & 37.04 \\
\hline Nurses & 63 & 25.92 \\
\hline Medical Students & 90 & 37.04 \\
\hline
\end{tabular}

Table.2 Responders and Non-Responders among Study Population

\begin{tabular}{|l|l|l|l|}
\hline & Total & $\begin{array}{l}\text { Responders } \\
(>\mathbf{1 0 m I U / m l})\end{array}$ & $\begin{array}{l}\text { Non-Responders } \\
(<\mathbf{1 0 m I U / m l})\end{array}$ \\
\hline Doctors & 90 & $87(96.67 \%)$ & $3(3.33 \%)$ \\
\hline Nurses & 63 & $57(90.48 \%)$ & $6(9.52 \%)$ \\
\hline Medical Students & 90 & $87(96.67 \%)$ & $3(3.33 \%)$
\end{tabular}


Table.3 Sex Distribution among Responders and Non-Responders

\begin{tabular}{|l|l|l|l|} 
& Total & $\begin{array}{l}\text { Responders } \\
(>\mathbf{1 0 m I U} / \mathbf{m l})\end{array}$ & $\begin{array}{l}\text { Non-Responders } \\
(<\mathbf{1 0} \mathbf{m I U} / \mathbf{m l})\end{array}$ \\
\hline Males & 141 & $132(93.62 \%)$ & $9(6.38 \%)$ \\
\hline Females & 102 & $99(97.06 \%)$ & $3(2.94 \%)$ \\
\hline
\end{tabular}

Chart.1 Responders Vs Non Responders

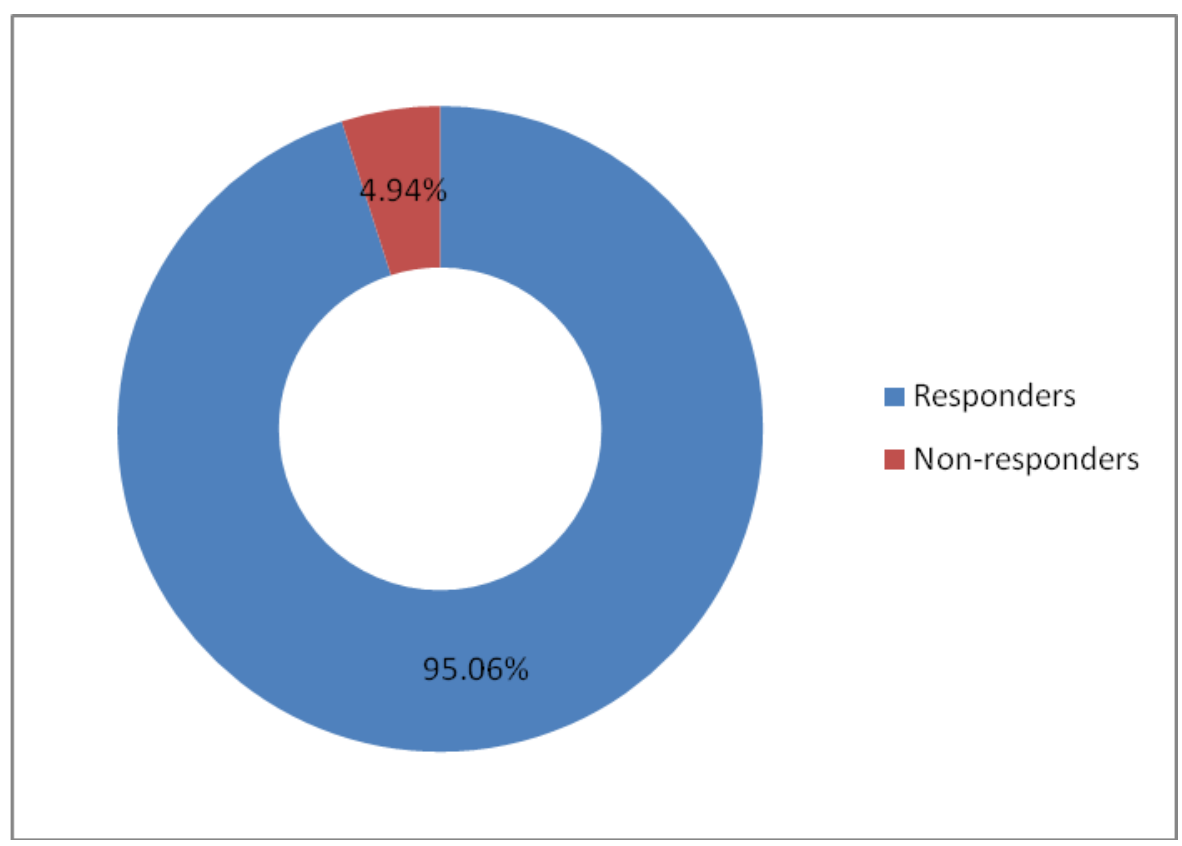

The response rate following HBV immunisation is higher in females when compared to males. The present study shows that $95.06 \%$ of Healthcare workers were immune to Hepatitis B virus (HBV) and $4.94 \%$ were not immune even after completing the full course of Hepatitis B vaccination. The above results correlate with the study done by Efim Platkov et al., among healthcare workers (Efim Platkov, 2003).

In another study conducted by (Mohammad Zeeshan et al., 2007), the percentage of responders was $86.2 \%$ which is less when compared our study which may be due to variation in other factors such as age and duration after completing the course of immunisation.
Our study results shows that the male non responders were more when compared to females which correlates with the study done by (Mohammad Zeeshan et al., 2007). The male non-responders were found to be more due to the factors such as smoking and increased body mass index (BMI) when compared to females (Surg Cdr et al., 2008).

Our study shows that the non-responders were high among nurses when compared to doctors and medical students. The study done by (Efim Platkov, 2003) also demonstrates that the non-responders among nurses were high which correlates with our study results.

The study done by (Yasaman Yaghobi et al., 2015) shows that $95.1 \%$ of medical students were responders and non-responders were 
4.9\% which correlates with our study, which may be due factors such as age and duration since vaccination is within 5 years.

In our study $95.06 \%$ of healthcare workers, after completing the full course of $\mathrm{HBV}$ vaccination were immune and $4.94 \%$ were non responders. The percentage of nonresponders can be brought down by checking the anti HBs level after completing the full course of vaccination and administrating the booster dose if the antibody level is found to be insufficient $(>10 \mathrm{mIU} / \mathrm{mL})$.

\section{References}

CDC. 2012 Case definitions: Nationally notifiable conditions infectious and noninfectious cases. Atlanta, GA: CDC; 2012.

CDC. Viral hepatitis statistics and surveillance. Available at http://www.cdc.gov/hepatitis/statistics/i ndex.htm

Dienstag JL, Werner BG, Polk BF, et al., Hepatitis B vaccine in health-care personnel: safety, immunogenicity, and indicators of efficacy. Ann Intern Med 1984; 101: 34--40.

Efim Platkov, Immunologic evaluation of Hepatitis B vaccine application in hospital staff. International Journal of Occupational Medicine and Environmental Health, 2003; 16(3): 249-253

Francis DP, Hadler SC, Thompson SE, et al., The prevention of hepatitis $\mathrm{B}$ with vaccine: report of the Centers for Disease Control multi-center efficacy trial among homosexual men. Ann Intern Med 1982; 97: 362--6.

Garibaldi RA, Forrest JN, Bryan JA, Hanson $\mathrm{BF}, \quad$ Dismukes WE (1973) Hemodialysis-associated hepatitis. JAMA 225: 384-389.

Gupta S, Gupta R, Joshi YK, Singh S (2008) Role of Horizontal Transmission in Hepatitis B Virus Spread among Household Contacts in North India. Intervirology 51:7-13.

Lauer JL, VanDrunen NA, Washburn JW, Balfour HH Jr (1979) Transmission of hepatitis B virus in clinical laboratory areas. J Infect Dis 140: 513-516

McMahon BJ, Bruden DL, Petersen KM et al., Antibody levels and protection after hepatitis B vaccination: results of a 15year follow-up. Ann. Intern. Med. 142, 333-341 (2005).

Mohammad Zeeshan et al., Evaluation of immune response to Hepatitis B vaccine in healthcare workers at a tertiary care hospital in Pakistan: an observational prospective study. BMC Infectious Diseases 2007, 7: 120 doi: $10.1186 / 1471-2334 / 7 / 120$

Previsani N, and Lavanchy D. World Health Organization. Hepatitis B (WHO/CDS/ CSR/LYO/2002.2). 2002

Prüss-Üstün A, Rapiti E, Hutin Y (2005) Estimation of the global burden of disease from sharps injuries to health-care workers. Am J Ind Med 48: 482-490.

Shaw FE Jr, Guess HA, Roets JM, et al., Effect of anatomic injection site, age and smoking on the immune response to hepatitis B vaccination. Vaccine 1989; 7: 425--30.

Surg Cdr et al., Antibody to hepatitis B surface antigen in vaccinated Health care workers; MJAFI 2008; 64: 329-332

US Public Health Service (2001) Updated U.S. Public Health Service Guidelines for the Occupational Exposures of HBV, HCV, and HIV and Recommendations for Post-exposure Prophylaxis. MMWR Recomm Rep 50: $1-52$.

Workers" IoHc. Recommendation of advisory committee on immunization practice (ACIP) and the Hospital infection Control Practice Advisory 
committee (HICPAC). MMWR, Recommendation and report 26; 12/26/97.

Yasaman Yaghobi et al., Serum Level of Anti-Hepatitis B Surface Antigen among Students in Guilan, Iran. Int J
School Health. 2015; 2(4): e28415. doi: 10.17795/intjsh28415.

Zajac BA, West DJ, McAleer WJ, Scolnick EM. Overview of clinical studies with hepatitis B vaccine made by recombinant DNA. J Infect 1986; 13(Suppl A): 39--45.

\section{How to cite this article:}

Ravikumar S., Radhika Katragadda and Abishek B. 2018. A Cross Sectional Study for Detection of Anti-HBs Antibody among Healthcare Workers. Int.J.Curr.Microbiol.App.Sci. 7(06): 1934-1939. doi: https://doi.org/10.20546/ijcmas.2018.706.229 